Volume 1 Nomor 2, Agustus 2016, halaman 83-92

\title{
PENGEMBANGAN PERANGKAT PENGAJARAN MATEMATIKA DENGAN PENDEKATAN PMR BERBANTUAN CD INTERAKTIF PADA MATERI PERSAMAAN LINEAR SATU VARIABEL KELAS VII
}

\author{
Ikin Zaenal Mutaqin \\ SMP Negeri 1 Pasekan, alfe.mutaqin@gmail.com
}

\begin{abstract}
ABSTRAK
Penelitian ini dimaksudkan untuk mengembangkan dan menghasilkan perangkat pembelajaran matematika dengan pendekatan PMR berbantuan CD interaktif pada materi persamaan linear kelas VII yang valid dan efektif. Hasil pengembangan perangkat pembelajaran matematika dengan pendekatan PMR pada materi persamaan linear satu variabel kelas VII menunjukkan hasil validasi dari para ahli. Implementasi dilapangan perangkat pembelajaran yang sudah valid dihasilkan perangkat yang efektif dengan variabel keaktifan dan keterampilan proses, yaitu mencapai tuntas belajar, adanya pengaruh keaktifan dan keterampilan proses terhadap hasil belajar dan ada perbedaan antara kelas kontrol dan kelas implementasi. Setelah implementasi diperoleh kesimpulan bahwa siswa mencapai tuntas belajar dengan $\mathrm{KKM}=65$ diperoleh ketuntasan 79,8. Terdapat pengaruh keaktifan dan keterampilan proses terhadap hasil belajar siswa sebesar $79,3 \%$. Terdapat perbedaan antara kelas kontrol $(66,7)$ dan kelas implementasi $(78,0)$. Sehingga dapat disimpulkan bahwa perangkat pembelajaran matematika dengan pendekatan PMR berbantuan CD interaktif pada materi PLSV kelas VII valid dan efektif.
\end{abstract}

Kata Kunci: Pengembangan, Pendekatan PMR, CD Interaktif.

\begin{abstract}
This study aimed to develop and produce devices PMR mathematics learning approach aided interactive $C D$ on the material linear equations class VII are valid and effective. The result of the development of mathematics learning with PMR approach on the material linear equations of one variable of class VII shows the validation results of the experts. Implementation field learning device that has generated valid and effective tool with active variable and process skills, reaching thoroughly studied, the effect of active variable and process skills to the learning outcomes and no difference between the control group and the implementation class. Once implemented obtained that result is students achieve a complete study with KKM = 65 gained 79.8 completeness. There is an active variable and process skills influence on the process of student learning outcomes by $79.3 \%$. There are differences between the control group (66.7) and the implementation class (78.0). It concluded that the study of mathematics by $P M R$ approach aided interactive $C D$ on material class VII PLSV valid and effective.
\end{abstract}

Keywords: Development, PMR approach, Interactive $C D$.

How to Cite: Mutaqin, I. Z. (2016). Pengembangan Perangkat Pengajaran Matematika dengan Pendekatan PMR Berbantuan CD Interaktif pada Materi 


\section{Persamaan Linear Satu Variabel Kelas VII. Mathline: Jurnal Matematika dan Pendidikan Matematika, Vol.1, No.2, 83-92.}

\section{PENDAHULUAN}

Matematika adalah salah satu pelajaran yang dikembangkan di seluruh negara di dunia ini. Ini tidak terlepas dari sifatnya sebagai pelayan ilmu pengetahuan yang lain. Matematika juga telah banyak memberikan sumbangan dalam perkembangan dan kemajuan ilmu pengetahuan dan teknologi. Banyak konsep dalam matematika yang erat sekali kaitannya dengan kehidupan sehari-hari.

Menurut kurikulum depdiknas tujuan umum diberikannya mata pelajaran matematika di SMP sesuai Permendiknas No. 22 tahun 2006 tentang standar isi adalah agar peserta didik memiliki kemampuan sebagai berikut.

a. Memahami konsep matematika, menjelaskan keterkaitan antarkonsep dan mengaplikasikan konsep atau algoritma, secara luwes, akurat, efisien, dan tepat, dalam pemecahan masalah.

b. Menggunakan penalaran pada pola dan sifat, melakukan manipulasi matematika dalam membuat generalisasi, menyusun bukti, atau menjelaskan gagasan dan pernyataan matematika.

c. Memecahkan masalah yang meliputi kemampuan memahami masalah, merancang model matematika, menyelesaikan model dan menafsirkan solusi yang diperoleh.

d. Mengomunikasikan gagasan dengan simbol, tabel, diagram, atau media lain untuk memperjelas keadaan atau masalah.

e. Memiliki sikap menghargai kegunaan matematika dalam kehidupan, yaitu memiliki rasa ingin tahu, perhatian, dan minat dalam mempelajari matematika, serta sikap ulet dan percaya diri dalam memecahkan masalah.

Sebagai implikasi dari penerapan Kurikulum Tingkat Satuan Pendidikan tersebut maka guru matematika diharapkan dapat melakukan penyesuaian atau perubahan terhadap pendekatan dalam menyajikan matematika kepada para siswanya. Guru matematika diharapkan bersedia meninggalkan pendekatan pengajaran matematika pola lama yang sekiranya sulit untuk mencapai tujuan pembelajaran yang lebih menekankan pada penataan nalar siswa. 
Ruseffendi (1988), mengemukakan bahwa pendekatan pembelajaran adalah suatu jalan, cara atau kebijakan yang ditempuh guru atau siswa dalam pencapaian tujuan pembelajaran dilihat dari sudut bagaimana proses atau materi pembelajaran itu, umum atau khusus dikelola. Soedjadi (1999), membedakan pendekatan pembelajaran matematika menjadi dua, sebagai berikut.

1) Pendekatan materi (material approach), yaitu proses penjelasan topik matematika tertentu menggunakan materi matematika lain.

2) Pendekatan pembelajaran (teaching approach), yaitu proses penyampaian atau penyajian topik matematika tertentu agar mempermudah siswa memahaminya.

Pendekatan yang dimaksud dalam tulisan ini adalah pendekatan pembelajaran, karena penelitian ini menekankan pada cara penyampaian materi matematika kepada siswa. Pembelajaran matematika realistik adalah suatu bentuk pendekatan dalam pendidikan matematika yang telah dikembangkan di Belanda oleh Freudenthal selama kurang lebih 38 tahun, yang dimulai sekitar tahun 1970. Pendekatan ini mengacu pada pendapat Freudental (Grafemeijer, 1994), yang menyatakan bahwa matematika harus dikaitkan dengan realita dan matematika merupakan suatu aktivitas manusia. Ini berarti matematika harus dekat dengan siswa dan matematika harus dikaitkan dengan situasi kehidupan sehari-hari. Matematika sebagai aktivitas manusia sehingga siswa harus diberi kesempatan untuk belajar melakukan aktivitas matematisasi pada topik-topik dalam matematika. Pendekatan semacam ini dikatakan Realistic Mathematic Education (RME).

Pengembangan model pembelajaran ini dilakukan dengan mendasarkan pada filosofi yang memandang matematika sebagai hasil kegiatan atau aktivitas manusia. Implementasi pandangan ini adalah sebuah bentuk pembelajaran matematika sekolah yang menganut pada prinsip re-invention atau "penemuan kembali". Menurut Soedjadi (2001), pembelajaran matematika realistik tidak diawali dengan memberikan definisi dan teorema, diikuti contoh penggunaannya dan pemberian masalah sebagai bahan latih siswa menerapkan definisi atau teorema itu, tetapi pengajaran matematika yang dirancang dengan memanfaatkan realistas dan lingkungan yang dipahami siswa. Yang dimaksud dengan realitas tersebut adalah hal-hal nyata atau konkret yang dapat diamati atau dipahami siswa lewat membayangkan. Sedangkan yang dimaksud dengan lingkungan tersebut adalah lingkungan tempat siswa berada. Pemanfaatan realitas dan lingkungan tersebut diwujudkan dalam bentuk soal cerita yang harus dipecahkan siswa. Dalam kegiatan pemecahan masalah ini dimungkinkan munculnya 
aktivitas matematisasi horizontal dan matematisasi vertikal. Matematisasi horizontal adalah proses transformasi masalah yang dinyatakan dalam bahasa sehari-hari ke bahasa matematika. Sedangkan matematisasi vertikal adalah proses dalam matematika itu sendiri. Dengan dorongan dan arahan guru, para siswa diberi kebebasan beraktivitas untuk menyelesaikan masalah tersebut yang bermuara pada penemuan kembali atau pengkonstruksian sifat, definisi, teorema atau aturan oleh siswa sendiri.

Grafemeijer (1994) menyebutkan tiga prinsip tersebut, yaitu (1) guided reinvention and progressive mathematizing (2) didactical phenomenology dan (3) self-developed models. Menurut Soedjadi (2001) pembelajaran matematika realistik mempunyai beberapa karakteristik sebagai berikut:

a. Menggunakan konteks, artinya dalam pembelajaran matematika realistik lingkungan keseharian atau pengetahuan yang telah dimiliki siswa dapat dijadikan sebagai bagian materi belajar yang kontekstual bagi siswa.

b. Menggunakan model, artinya permasalahan atau ide dalam matematika dapat dinyatakan dalam bentuk model, baik model dari situasi nyata maupun model yang mengarah ke tingkat abstrak.

c. Menggunakan kontribusi siswa, artinya pemecahan masalah atau penemuan konsep didasarkan pada sumbangan gagasan siswa.

d. Interaktif, artinya aktivitas proses pembelajaran dibangun oleh interaksi siswa dengan siswa, siswa dengan guru, siswa dengan lingkungan dan sebagainya.

Langkah-langkah pembelajaran dengan pendekatan PMR pada penelitian ini adalah sebagai berikut.

\section{Langkah - 1. Memahami masalah kontekstual}

Pada langkah ini guru menyajikan masalah kontekstual kepada siswa. Selanjutnya guru meminta siswa untuk memahami masalah itu terlebih dahulu.

Karakteristik pembelajaran matematika realistik yang muncul pada langkah ini adalah menggunakan konteks..

\section{Langkah - 2. Menjelaskan masalah kontekstual.}

Langkah ini ditempuh saat siswa mengalami kesulitan memahami masalah kontekstual. Pada langkah ini guru memberikan bantuan dengan memberi petunjuk atau pertanyaan seperlunya yang dapat mengarahkan siswa untuk memahami masalah. 


\section{Langkah - 3. Menyelesaikan masalah kontekstual.}

Pada tahap ini siswa didorong menyelesaikan masalah kontekstual secara individual berdasar kemampuannya dengan memanfaatkan petunjuk-petunjuk yang telah disediakan. Siswa mempunyai kebebasan menggunakan caranya sendiri.

\section{Langkah - 4. Membandingkan dan mendiskusikan jawaban}

Pada tahap ini guru mula-mula meminta siswa untuk membandingkan dan mendiskusikan jawaban dengan pasangannya. Diskusi ini adalah wahana bagi sepasang siswa mendiskusikan jawaban masing-masing. Dari diskusi ini diharapkan muncul jawaban yang dapat disepakati oleh kedua siswa.

\section{Langkah - 5. Menyimpulkan}

Dari hasil diskusi kelas guru mengarahkan siswa untuk menarik kesimpulan mengenai pemecahan masalah, konsep, prosedur atau prinsip yang telah dibangun bersama. Pada tahap ini karakteristik pembelajaran matematika realistik yang muncul adalah interaktif serta menggunakan kontribusi siswa.

Berdasarkan uraian di atas, dapat ditarik sebuah kesimpulan bahwa pembelajaran matematika realistik adalah sebuah pendekatan yang mempunyai peluang untuk diterapkan dalam upaya perbaikan mutu pendidikan matematika di Indonesia seiring dengan pemberlakuan Kurikulum Tingkat Satuan Pendidikan. Sebagai sebuah pendekatan yang baru, pembelajaran matematika realistik tidak dapat serta merta atau otomatis berjalan lancar tanpa hambatan. Pada awal pelaksanaannya diperlukan sejumlah penyesuaian baik pada tataran konsepsional maupun operasional, karena ada beberapa prinsip dan karakteristik dari pendekatan ini yang merupakan hal baru bagi guru maupun siswa di Indonesia. Sehingga tujuan dari penelitian ini adalah sebagai berikut.

1. Diperoleh pengembangan perangkat pembelajaran matematika dengan pendekatan PMR berbantuan CD interaktif pada materi persamaan linear satu variabel kelas VII yang valid.

2. Untuk mengetahui bahwa pembelajaran matematika melalui pendekatan PMR berbantuan CD Interaktif pada materi persamaan linear kelas VII efektif.

\section{METODE PENELITIAN}


Dalam kaitannya dengan pengembangan model pembelajaran tertentu, Plomp (1997) mgajukan suatu model yang bersifat lebih umum dalam merancang pendidikan (termasuk pembelajaran). Ada 5 tahap yang dilalui dalam pengembangkan model, yaitu :

\section{Tahap Pengkajian Awal}

Tahap ini merupakan tahap analisis kebutuhan atau masalah yang mencakup (a) pengkajian teori-teori yang relevan, (b) pengidentifikasian informasi, (c) analisis informasi, (d) mendefinisikan/ membatasi masalah, dan (e) merencanakan kegiatan lanjutan.

\section{Tahap Perancangan}

Kegiatan pada tahap ini bertujuan untuk merancang penyelesaian masalah yang telah diidentifikasikan pada tahap pertama, Rancangan yang dibuat meliputi suatu proses yang sistematik dengan membagi-bagi masalah besar menjadi masalah-masalah kecil dengan rancangan pemecahannya masing-masing, kemudian pada akhimya semua bentuk solusi dikumpulkan dan dihubung-hubungkan kembali menjadi suatu struktur pemecahan masalah secara lengkap

\section{Tahap Realisasi/Konstruksi}

Pada tahap ini dibuat prototipe, yaitu rancangan utama yang berdasarkan pada rancangan awal. Dalam konteks pendidikan, tahap kedua dan ketiga di atas disebut tahap produksi.

\section{Tahap Tes, Evaluasi, dan Revisi}

Tahap ini bertujuan mempertimbangkan mutu dari rancangan yang akan dikembangkan. Juga membuat keputusan melalui pertimbangan yang matang. Evaluasi mencakup proses menghimpun, memproses dan menganalisis informasi secara sistematis. Hal ini dilakukan untuk menilai kualitas pemecahan yang dipilih. Selanjutnya direvisi kemudian kembali kepada kegiatan merancang, dst. Siklus yang terjadi ini merupakan siklus umpan balik dan berhenti setelah memperolah pemecahan yang diinginkan.

\section{Tahap Implementasi}

Pada tahap ini pemecahan telah diperoleh setelah melalui evaluasi. Pemecahan tersebut dianggap memenuhi masalah yang dihadapi. Karena itu pemecahan yang dipilih dapat diimplementasikan atau diterapkan dalam situasi yang sesungguhnya.

\section{HASIL DAN PEMBAHASAN}


Pengembangan perangkat pembelajaran matematika dengan pendekatan PMR berbantuan $\mathrm{CD}$ interaktif ini mengacu pada model pengembangan pendidikan umum dari Plomp (1997) yang terdiri dari beberapa tahap yakni (1) tahap investigasi awal, (2) tahap perancangan (design), (3) tahap realisasi/konstruksi, (4) tahap pengujian, evaluasi dan revisi, dan (5) tahap implementasi. Hasil pengembangan setiap tahap dalam pengembangan perangkat pembelajaran ini adalah sebagai berikut.

\section{Tahap Investigasi Awal}

Dalam tahap ini dilakukan identifikasi dan kajian terhadap perangkat pembelajaran matematika dengan PMR berbantuan CD interaktif, kurikulum matematika, kondisi siswa dan tuntutan lingkungan terhadap pembelajaran matematika. Berdasarkan pada kegiatan pra survei yang telah dilakukan bersamaan dengan pra survei pengembangan perangkat, telah diperoleh asumsi bahwa (1) aktivitas siswa bisa ditingkatkan dengan siswa menemukan sendiri konsep, (2) kegiatan kelompok dan presentasi yang sebelumnya tidak dikenal siswa bisa dilatihkan dengan pembelajaran matematika dengan PMR berbsntuan CD interaktif, (3) siswa-siswa pada dasarnya bisa mengkomunikasikan ide-ide di depan kelas dengan baik, apabila mereka dibiasakan untuk melakukannya di dalam kelas, dan (4) mereka sebenarnya menyukai cara belajar yang inovatif seperti pembelajaran matematika dengan PMR berbantuan CD interaktif.

\section{Tahap Perancangan}

Berdasarkan kajian teori pada tahap investigasi awal, pada tahap ini dirancang perangkat pembelajaran matematika dengan PMR berbantuan CD interaktif. Perangkat pembelajaran yang dirancang adalah RPP, LKS, BAS, THB, dan CD interaktif. RPP yang dirancang memuat pendahuluan, kegiatan inti dan penutup. LKS dirancang untuk membimbing, mengarahkan dan menuntun siswa dalam menemukan rumus. BAS dirancang untuk membimbing, mengarahkan dan menuntun pemahaman siswa terhadap rumus (konsep), CD interaktif dirancang untuk membimbing, mengarahkan dan menuntun siswa dalam mengerjakan LKS, dan THB dirancang untuk mengukur tingkat pemahaman siswa terhadap rumus (konsep) yang telah didapatnya. Semua dirancang dengan mengacu pada pembelajaran matematika dengan PMR berbantuan CD interaktif yang dikembangkan.

\section{Tahap Realisasi/Konstruksi}


Pada tahap ini dibuat/disusun suatu perangkat pembelajaran yaitu RPP, LKS, BAS, THB dan CD interaktif yang sesuai dengan pembelajaran matematika dengan PMR berbantuan $\mathrm{CD}$ interaktif. Perangkat pembelajaran yang dihasilkan dalam tahap ini selanjutnya disebut dengan draf 1 perangkat pembelajaran matematika dengan PMR berbantuan CD interaktif.

\section{Tahap Pengujian, Evaluasi dan Revisi}

Pada tahap ini dimaksudkan untuk mengetahui dua hal, yakni: (1) apakah perangkat pembelajaran (draf 1) yang telah didesain dan disusun secara rinci pada tahap kedua dan ketiga sudah layak menurut pertimbangan ahli, (2) secara praktis dapat diterapkan di kelas, dan (3) apakah tujuannya tercapai. Berikut ini hasil pengembangan perangkat pembelajaran yang diperoleh selama tahap ini. Rekapitulasi hasil validasi terhadap perangkat pembelajaran dapat dilihat pada berikut.

Tabel 1. Rekapitulasi Hasil Penilaian Validator

\begin{tabular}{lrrrrrl}
\hline \multicolumn{1}{c}{ Perangkat Pembelajaran } & \multicolumn{4}{c}{ Validator } & \multirow{2}{*}{ Rumlah } & \\
\cline { 1 - 5 } & $\mathbf{1}$ & $\mathbf{2}$ & $\mathbf{3}$ & $\mathbf{4}$ & & \\
\hline RPP & 3,82 & 4,24 & 4,16 & 4,40 & 16,62 & 4,20 \\
LKS & 3,88 & 3,88 & 3,90 & 4,40 & 16,06 & 4,01 \\
CD Interaktif & 3,75 & 3,85 & 3,95 & 3,95 & 15,40 & 3,85 \\
THB & 4,00 & 4,25 & 4,00 & 4,50 & 16,76 & 4,188 \\
Bahan Ajar & 3,21 & 4,125 & 4,125 & 3,75 & 15,2 & 3,80 \\
\hline
\end{tabular}

Pada Tabel 1 dapat dilihat bahwa rata-rata penilaian validator perangkat pembelajaran berada pada interval 3,40 dan 5,00. Sesuai dengan kriteria yang telah ditentukan bahwa perangkat pembelajaran berkriteria baik. Berdasarkan kriteria yang telah ditetapkan maka perangkat pembelajaran yang dikembangkan termasuk dalam kategori valid dan sangat valid. Dengan demikian penelitian pengembangan ini telah dihasilkan perangkat pembelajaran yang valid.

\section{Tahap Implementasi}

Setelah perangkat pembelajaran dilakukan uji coba pada tahap 4 (pengujian, evaluasi dan revisi), sehingga dihasilkan perangkat pembelajaran matematika dengan pendekatan PMR berbantuan $\mathrm{CD}$ interaktif yang valid, kemudian dilanjutkan dengan mengimplementasikan perangkat tersebut pada situasi yang sesungguhnya. Implementasi perangkat pembelajaran dilakukan untuk mendukung implementasi pengajaran dan untuk 
mengetahui apakah perangkat pembelajaran benar-benar telah sesuai dengan pembelajaran matematika dengan pendekatan PMR berbantuan CD interaktif.

Subjek implementasi (uji coba kedua) dilaksanakan pada kelas VIIC dengan jumlah siswa 32 orang. Tahap uji coba ini dilakukan untuk menguji hipotesis kedua yaitu diperolehnya perangkat pembelajaran matematika dengan efektif, yaitu dengan menguji (a) Ketuntasan hasil belajar siswa dengan KKM yang ditetapkan adalah 6,5 (b) Perbedaan anata kelas kontrol dengan kelas yang terkena implementasi, dan (c) pengaruh keaktifan dan sikap siswa tehadap hasil belajar.

\section{KESIMPULAN}

Berdasarkan hasil-hasil pengembangan dan diskusi hasil penelitian yang dikemukakan di atas, maka dapat dikemukakan kesimpulan penelitian pengambangan perangkat pembelajaran matematika dengan pendekatan PMR berbantuan CD interaktif pada materi PLSV kelas VII dikembangkan berdasarkan tahapan Plomp (1997), yakni (1) tahap investigasi awal, (2) tahap design/perancangan, (3) tahap realisasi/konstruksi, (4) tahap pengujian, evaluasi dan revisi, dan (5) tahap implementasi. Dalam proses pengembangan dihasilkan :

1. Perangkat pembelajaran matematika dengan pendekatan PMR berbantuan CD interaktif yang dikembangkan valid menurut penilaian ahli.

2. Perangkat pembelajaran matematika dengan pendekatan PMR berbantuan CD interaktif materi PLSV kelas VII diiplemtasikan atau diujicobakan dan menghasilkan perangkat pembelajaran yang efektif, dimana siswa mencapai tuntas belajar, ada perbedaan rata-rata kemampuan siswa kelas implementasi dengan kelas kontrol, dan adanya pengaruh keaktifan dan sikap siswa terhadap hasil belajar. Sehingga dihasilkan perangkat pembelajaran matematika dengan pendekatan PMR berbantuan CD interaktif yang valid, dan efektif.

Berdasarkan kesimpulan yang dikemukakan tersebut, maka untuk penelitian lanjutan peneliti mengharapkan:

1. Karena perangkat pembelajaran matematika dengan pendekatan PMR berbantuan CD interaktif, CD interaktif merupakan sumber utama dalam kegiatan pembelajaran, dan agar siswa benar-benar terbantu dalam merealitikan pengetahuannya, sebaiknya CD yang 
dirancang benar-benar interaktif, bukan sebatas CD interaktif yang dirancang dalam perangkat pembelajaran ini.

2. Pengembangan perangkat pembelajaran dengan pendekatan pembelajaran matematika realistik hendaknya dikembangkan juga untuk pokok bahasan lainnya agar dapat menumbuhkan minat siswa untuk belajar matematika.

3. Sebaiknya jika pengembangan perangkat pembelajaran dan instrumen penelitian tidak dalam waktu yang bersamaan.

4. Hasil penelitian ini merupakan gambaran dari satu kelas sampel, oleh karena itu perangkat ini dapat diujicobakan lagi pada kelas-kelas lain agar dapat diperoleh perangkat pembelajaran yang lebih baik.

\section{DAFTAR PUSTAKA}

Grafemeijer, K. P. E. (1994). Developing Realistic Mathematics Education. Nedherlands: Freudental Institute, Utrecht CD- $\beta$ Press.

Plomp, Tjeerd. (1997). Educational and Training System Design. Nedherlands: University of Twente.

Russeffendi. (1988). Dasar-Dasar Matematika Modern. Bandung: Transito.

Soedjadi, R. (1999). Kiat Pendidikan Matematika di Indonesia. Jakarta: Depdiknas.

Soedjadi, R. (2001). Media Pendidikan Matematika: Memantapkan Matematika Sekolah sebagai Wahana Pendidikan dan Pembudayaan Penalaran. Surabaya: UNESA. 